\title{
Central European Journal of International and Security Studies
} Vol. I5, No. 3, 202I, pp. 4-29

DOI: I0.51870/CEJISS.AI5030I

Research article

\section{Indivisible Security and Collective Security Concepts: Implications for Russia's Relations with the West}

\author{
Artem Kvartalnov \\ Moscow State Institute of International Relations (MGIMO University), \\ ORCiD: 0000-0002-5120-I64I; corresponding address: artem@kvartalnov.ru ${ }^{\mathrm{I}}$
}

\begin{abstract}
The indivisible security principle was first set out in the 1975 Helsinki Final Act and since then has been included in numerous international treaties and national strategic documents. However, the concept remains ambiguous and has not received due attention. The collective security concept has in turn been studied extensively by researchers who represent different paradigms and who have come up with diverse understandings of the term. This article adds to the ongoing conceptualisation of collective security and indivisible security and considers the implications of both concepts for European and global security arrangements in the context of Russia's relations with the West. First, I analyse the history of the indivisible security and collective security concepts and briefly review relevant literature. Further, I come up with my conceptualisation of both notions, illustrating the theoretical claims with the case of Russia's relations with NATO and EU countries. Building on this analysis, I assess the implications of both approaches for European and global security. I conclude that the international system cannot solely rely on either collective security or indivisible security and state the need for a middle-ground approach based on the decoupling/compartmentalisation of different policy areas.
\end{abstract}

Keywords: indivisible security, collective security, network diplomacy, NATO, OSCE, Russia

First published online on I7 September 202I, issue published on I7 September $202 \mathrm{I}$

I Moscow State Institute of International Relations (MGIMO University), a visiting student at The Fletcher School of Law and Diplomacy at Tufts University and a member of the Young Deep Cuts Commission.

(C) 202I CEJISS. Article is distributed under Open Access licence: Attribution - NonCommercial 3.0 Unported (cc by-nc 3.0). 


\section{Introduction}

The perceived objective of any modern security policy is to sustain peace. Whatever policymakers do, official documents and statements call for peace, reconciliation and stability. War is not appealing today, and the desire for it has been largely marginalised. Nevertheless, wars, conflicts and tensions are still there, and they usually result from mutual misperceptions and misunderstandings emerging in the pursuit of peace rather than from innate aggressiveness. This insight has pushed international relations scholars into studying security dilemmas, ${ }^{1}$ cybersecurity dilemmas, ${ }^{2}$ integration dilemmas, ${ }^{3}$ identity issues,${ }^{4}$ etc. However, international relations scholarship has not done enough to endogenise some of the visions of security that underlie competing approaches to international politics. This appears to be an obstacle to further research, as longstanding disputes about the future world order may lack real content.

This article discusses two opposing notions that have featured prominently in the European political discourse: indivisible security and collective security. My theoretical argument is that both concepts are flawed in terms of global vision because they largely neglect the barriers to their universal implementation. More specifically, neither of the two concepts can serve as the sole basis of a smoothly functioning world order because collective security leads to exclusion and inequality, whereas indivisible security lacks efficient problem-solving mechanisms. To illustrate this point, I use a case study of Russia's relations with the West. My empirical argument is twofold. On the one hand, I demonstrate that Russia's foreign policy after I99I has been more consistent than usually assumed. On the other hand, I show that the full-fledged implementation of the indivisible security concept that Russia has been calling for would not necessarily be in Russia's interest.

The paper is organised as follows. First, I consider the history of indivisible security and collective security approaches and the conditions associated with the rise of both concepts, as well as briefly review their theoretical foundations and relevant literature. Further, I trace the hidden meaning of these notions and the underlying contradictions, illustrating my theoretical claims with the case study. Based on this analysis, I assess the implications of both approaches for European and global security and come up with my conclusions.

\section{Historical background}

Although the idea of collective security can be traced back to Kant's Perpetual Peace, ${ }^{5}$ it saw its heyday only in the $20^{\text {th }}$ century. Article X of the Covenant of the League of Nations provided for collective action against security threats. ${ }^{6}$ The League failed to deter German, Italian and Japanese aggression, and the collective security concept was overshadowed by the idea of collective defence after World War II. NATO and the Warsaw Pact are the most obvious manifestations 
of the collective defence tradition. Starting as purely military tactical arrangements at the beginning of the $20^{\text {th }}$ century, collective defence organisations evolved into value-laden regional bodies of like-minded countries. A collective defence organisation brings together the countries that rule out the possibility of war among them and are eager to pursue common security goals, considering 'an attack against one Ally <...> as an attack against all Allies'. The relevance of such a security pattern increases in hard times, when nations have difficulty trusting one another. This was the case at the beginning of the Cold War, when the foundation for the modern European security architecture was laid. Collective defence was a new beginning for the notion of collective security: after the collapse of the bipolar world order, NATO assumed responsibility for maintaining security in and around Europe, going beyond the classical logic of collective defence. ${ }^{8}$ The new tradition of collective security is exclusive rather than inclusive, since it does prioritise the security of some nations and regions over the security of others. It is apparent in political uses of the term: for instance, in 2002, Russia and its allies established the Collective Security Treaty Organization (CSTO), ${ }^{9}$ which is actually based on the collective defence posture.

The advent of indivisible security is associated with different circumstances. The Helsinki Final Act of 1975, where the principle of equal and indivisible security was set out, signified the willingness of countries in the Euro-Atlantic area to maintain the status quo and to sustain peace. The principle of indivisible security implied that '[c]o-operation is beneficial to all participating States, while the insecurity in or of one participating State can affect the well-being of all.' ${ }^{10} \mathrm{In}$ practice, this means that 'States will not strengthen their security at the expense of other States.'I The notion of indivisible security has not received due attention from the academic community; it remains underconceptualised and has been seen by some scholars as vague and even destructive. ${ }^{12}$ However, indivisible security is still there: the notion was explicitly mentioned in the I990 Charter of Paris for a New Europe,,$^{13}$ the I997 NATO-Russia Founding Act, ${ }^{14}$ as well as in the 1999 Charter for European Security. ${ }^{15}$ The term 'indivisible security' has been included in all major Russian strategic documents since $2000 .{ }^{16}$

\section{Literature review and discussion of the concepts}

The concepts of collective security and indivisible security, as well as related ideas, have been addressed by scholars working in both realist and idealist traditions. An important feature of analyses focusing on collective security is their diversity in terms of the existing conceptualisations of what collective security is and how effective it can be.

Williams and Jones view modern collective security as a continuation of the tradition of the early $20^{\text {th }}$ century that has been discussed above. From their per- 
spective, collective security is 'definitely not an idea or concept whose time has now come. ${ }^{17}$ To substantiate this opinion, the authors cite the failure of collective security in the I930s in the case of 'Italy's sudden and unprovoked attack on Abyssinia, ${ }^{18}$ when no member of the League of Nations reacted properly to the obvious violation of international norms. Williams and Jones believe that the United Nations Security Council (UNSC) assumed the role of the League of Nations after World War II, leading to few meaningful changes in the implementation of collective security. 'The Security Council found it difficult to agree on who was the real aggressor, and, then as a result, its permanent members have split and backed one or other of the belligerents involved. This, in turn, let the conflict take its natural course and the outcome was then determined on the battlefield.' ${ }^{19}$ Those few endeavours that were successful are described as not really collective, since they were 'under American tutelage. ${ }^{20}$

Applying this theoretical framework to Western alliances, Williams and Jones introduce the idea that collective security is hardly feasible due to the inherent differences between security and defence. They point out that defence issues identified as such do not usually cause debates among allies, which is why it is quite easy to agree on the concerted reaction to a defence crisis, such as the $\mathrm{Cu}$ ban missile crisis of 1962. In contrast, a security issue does not imply an immediate threat; therefore, diverging economic and political interests make a prompt concerted reaction hardly possible. ${ }^{2 \mathrm{I}}$

Charles A. Kupchan and Clifford A. Kupchan adopted a different reference point. While analysing the collective security concept, they do not compare it with collective defence. What they emphasise is that 'collective security is preferable to balancing under anarchy.'.22 The authors' vision of collective security goes well with the understanding I stick to. The Kupchans highlight that '[a]ny institution that is predicated upon the principles of regulated balancing and all against one falls into the collective security family. ${ }^{23}$ From their perspective, the key advantages of collective security are 'more effective balancing against aggressors' and the promotion of 'trust and cooperation.'24

Mearsheimer views collective security as one of several approaches that emphasise the role of international institutions. Being a structural realist, he calls the assumptions of collective security into question. First, he points out that a collective security system can only deal with one or two threats concurrently, which may be not enough in realist global politics. ${ }^{25}$ Second, 'states [of a collective security system] are likely to remain on the sidelines if [their] vital interests are not threatened. ${ }^{26}$ Third, Mearsheimer points out that collective security necessitates trust, which is certainly scarce in the international system. ${ }^{27}$

Even though the concepts of collective security and indivisible security do overlap sometimes, they are characterised by different emphases. This can be 
clearly seen in literature dealing with the problem of creating a pan-European security architecture from the perspective of indivisible security. MccGwire pinpoints that security in Europe 'is conceptually distinct' from the security of Europe: the latter assumes 'an external threat to a Europe that does not include Russia', whereas the former 'is a more inclusive concept, reaching from the Atlantic to the Urals. ${ }^{28}$ According to MccGwire, 'the concepts of threat and security are highly subjective, $<\ldots>$ one country's security can be another's insecurity,' which is why 'it is counterproductive to focus on the security concerns of one or a few countries. ${ }^{29}$ MccGwire's key conclusion (his article was published in 1998) is that NATO enlargement 'threatens Washington's cooperative relationship with Moscow' ${ }^{\circ}$

Russian scholars studying the topic typically arrive at similar conclusions. As Zagorski put it in 20I4, '[i]n spite of the declared adherence to the principle of indivisible cooperative security, the levels of security in different parts of the OSCE [Organization for Security and Co-operation in Europe] area remain different. The conventional arms control regimes, which in the past decades ensured reductions in armed forces and armaments unprecedented in the history of Europe, have gone into decline..3

Ellehuus and Zagorski maintain that 'Treaty organizations such as NATO and the European Union could increase transparency with Russia and stability on the European continent by acknowledging the OSCE language on indivisible security requiring the legitimate security concerns of neighboring states to be considered. ${ }^{32}$

However, the Russia-friendly perspective on indivisible security is not the only one. Remler from the Carnegie Endowment for International Peace rightly believes that Russia itself abuses the indivisible security concept. First, he points out that Russia insists on decoupling security issues from human rights, which actually violates the spirit of the Helsinki Final Act. Second, he emphasises that the Istanbul Charter for European Security adopted by Russia acknowledges 'the inherent right of each and every participating State to be free to choose or change its security arrangements, including treaties of alliance. 33

My paper builds on many of these perspectives. I will briefly comment on some of them to better illustrate the theoretical framework that I draw on. First, I do not call into question the feasibility of either of the two concepts. Both collective security and indivisible security are useful principles that can guide international security relations. Even if a collective security organisation may fail to deal with more than two major threats simultaneously, the existence of such an organisation does entail real-world consequences, such as a plausible deterrence effect and the enormous effect that NATO enlargement has had on the Russian foreign policy discourse. Moreover, the I990s saw a number of NATO 
interventions that succeeded despite the fact that those interventions were not a question of defence. Similarly, even though Russia seems to abuse the indivisible security concept, the concept itself continues to be viable and attractive, as it has a solid ideational basis. Second, I insist that collective security is an exclusive rather than inclusive security concept. 'All against one' institutions are necessarily limited to their members, which means that those outside are left aside. This is true even for the UN collective security system, since those outside of the UNSC have no voice when collective security decisions are made.

For the purposes of this study, collective security can be defined as a principle of providing security for a limited number of nations by a limited number of nations. Indivisible security is the principle of providing equal security to all nations regardless of their political, economic or ideological commitments.

\section{Mechanisms and political implications}

The collective security and indivisible security concepts entail real-world consequences in terms of the way regional and global security systems are arranged. Collective security is granted only to those who meet particular criteria (Castells calls such a relationship 'networking power'). ${ }^{34}$ This logic appears justifiable, as modern collective security organisations, which originated from collective defence structures, are still based on the collective defence posture: it would be unwise to guarantee equal political and military assistance to any country, as the League of Nations attempted to do so and is known to have failed. We do not have enough evidence to determine whether NATO's Article 5 works: it might prove to be another self-fulfilling myth that would collapse in case of a real threat. However, the history of the League of Nations makes us acutely aware of the fact that collective security most likely cannot work without the underlying exclusiveness principle. NATO does engage in security efforts beyond its borders, but it does not provide guarantees to outsiders. Within the framework of collective security, commitment to principles and loyalty to allies are generally prioritised over strict compliance with international law and respect for the interests of non-member states. Thus, security groupings tend to overestimate their ability to address international issues single-handedly and frequently neglect potential cooperation opportunities.

The opposite is the case with indivisible security. The concept of indivisible security is not purely Russia's justification for its quest for 'the non-aligned status of the buffer states. ${ }^{\prime}{ }^{5}$ It is a vision of security that rules out the possibility of any strict preconditions for elaborating an integrated peace strategy. If some countries co-exist in a particular region, they are supposed to have common security interests. Consequently, they need inclusive international platforms to communicate. The concept of indivisible security emphasises the need for equal, 
written rules to regulate international behaviour and does not recognise the right of nations to act on the basis of 'narrow loyalties' to friends and allies. As Russia's Foreign Minister Sergey Lavrov put it in Baku in 2017, 'a situation where some are provided with clear legal guarantees, while others must be content with promises no one is going to fulfill, is unacceptable. ${ }^{36}$ Whether countries within an indivisible security framework can assume substantive legally binding security obligations in theory is an open question. In practice, the resulting security architecture is typically confined only to deliberative bodies, such as conferences and councils, and restrictive norms, such as the Treaty on Conventional Armed Forces in Europe (CFE Treaty) ${ }^{37}$ or the Anti-Ballistic Missile Treaty (ABM Treaty $)^{38}$ - without any real mutual security guarantees.

Both indivisible security and collective security imply a certain underlying peace strategy. Under collective security, peace is attained through the enlargement of the 'area of harmony', existing inside a collective security organisation. This organisation must be institutionally strong from the very beginning, and it must be based on absolute trust among its members (which is seen as impossible by Mearsheimer, as noted above). The area of stability and peace can hypothetically engulf the entire world, as soon as each and every country commits itself to the norms and values adopted by the collective security organisation. Therefore, the enlargement of a grouping is seen as the right path towards achieving better security for everyone by means of granting complete security to some nations. NATO enlargement can be viewed as a mechanism of socialising less developed nations into the community of countries that have developed new 'security mindsets' ${ }^{39}$ Whether an enlargement is a real success on the road to peace is determined by the extent to which new members have developed these new mindsets and joined the 'area of harmony'.

The indivisible security concept rejects this reasoning and legitimately points to the inequality resulting from the collective security approach. Strong security guarantees can hardly ever embrace the entire world, which is why collective security organisations simply embody better access to security for some nations, excluding the rest of the globe. Missile defence systems and new military bases are a sure way to enter into a new arms race. Consequently, it might seem more reasonable to gradually develop equal arrangements for everyone, even if these arrangements turn out imperfect and incomplete. Better security for everyone is achieved by means of granting some security to every nation. In the long run, weak inclusive institutions can hypothetically evolve into a comprehensive security architecture, sustaining peace in a whole region or even throughout the world.

Apparently, contradictions between the two notions of security are inevitable. Those outside an exclusive security organisation have no reason to toler- 
ate exclusion. Under a collective security system, the most important issues are discussed by the insiders (since they trust each other and tend to stick together), while the resulting decisions are implicitly imposed on the outsiders, who simply lack institutional capabilities to state their position. Those inside, for their part, have no incentive to give up the unprecedented level of security just to become equal participants of fragile 'inclusive' security arrangements.

The pattern described above roughly reflects the collision between different visions of European security and the positions adopted by NATO countries and by the Russian Federation respectively. Russia has been denouncing NATO enlargement for decades, advocating a special role for the Organization for Security and Co-operation in Europe (OSCE) and 'pan-European security structures'. However, the clash between indivisible and exclusive collective security approaches represents an analytical framework that could hypothetically be applied to different regions and eras. Therefore, this collective security VS. indivisible security dilemma deserves particular attention.

\section{Collective security and the world order}

The first problem with exclusive collective security organisations has already been mentioned: they are too tight to meet everyone's expectations. The 'area of democracy and peace' is a nice idea, but it is increasingly unclear if it can be universally implemented in practice. Historical evidence demonstrates that political unity rarely lasts long: Watson's pendulum theory ${ }^{40}$ suggests that international politics constantly swings between empire and anarchy. Thus, the democratic peace order is unlikely to preserve its cohesiveness in the long run after achieving the state of dominance, and Western scholars seem to be perfectly aware of this fact. ${ }^{4 \mathrm{I}}$ This does not necessarily mean the demise of democracy itself: the point is that nations may easily start a new extended dispute, having agreed on democratic principles. Some scholars hope that Western material hegemony can establish effective rules ensuring security and prosperity after its decline. ${ }^{42}$ This hope may turn out to be misplaced: modern nation-states defeated empires, set new comprehensive rules, and simply split up into capitalists, socialists, democrats and dictators, creating new confrontation lines. This is what can (but will not necessarily) happen to a democratic collective security institution whose values have evolved into the global norm and eliminated alternative visions. Therefore, the enlargement of a collective security organisation is both a blessing and a curse: it helps to strengthen security, simultaneously creating risks of disintegration in the long term.

The processes of NATO and EU enlargement have already caused this threat to become apparent. When Eastern European countries were admitted to Western political and economic institutions, the US was able to tighten control over 
Europe, since such countries as Poland and Hungary viewed (and continue viewing) Washington rather than Brussels as the provider of their security. ${ }^{43}$ Autonomist trends did recede: the 1992 Petersberg Declaration of the Western European Union (WEU) calling for the empowerment of the $\mathrm{WEU}^{44}$ has never been implemented, whereas NATO continued to play the role of Europe's military defender. What followed later was, however, a trend towards disintegration in the ideational domain. Today, Poland and Hungary are viewed as key challengers of European values. This newly established dividing line creates problems for the European consensual decision-making framework.

The second challenge is closely connected with the first one. As modern collective security institutions prioritise the security of member states, those outside may protest by means of undermining the activities of the organisation in question or establishing competing institutions, which might create another cold war situation. The 'area of harmony' can simply be destroyed by those who were not included in it.

This is exactly the type of activity that Russia has been engaged in. Being unable to join the privileged grouping, Moscow has been trying to undermine the heightened security level of NATO countries. Several dimensions of this can be identified. First, Russia has done a lot to neutralise any kind of missile defence in Europe and North America. As Russian Deputy Prime Minister Borisov put it in 2018, Russia's hypersonic glide vehicle Avangard 'almost nullifies missile defence'.45 Moscow's hypersonic weapons certainly add to the insecurity of NATO. Second, Russia denied Europe a high level of security in the tactical domain by suspending the CFE Treaty in 2007 and 'completely' halting participation in the Treaty in $2015 .^{46}$ Third, Russia has allegedly attempted to disrupt Western political systems by means of carrying out election meddling ${ }^{47}$ and providing support for right-wing forces in EU countries. ${ }^{4}$

Hence, there are two diametrically opposed negative scenarios for an order based on collective security. The first scenario implies the destruction of the leading collective security organisation by those dissatisfied with its dominant position. The second scenario is the disintegration of the grouping after achieving global or regional hegemony, which derives from the 'laws of history'.

A stable collective security system requires balancing between the two poor outcomes. I posit that perfect balancing draws on several complementary strategies.

\section{Luring}

The luring strategy is designed to avoid the first scenario. If a collective security organisation provides an outstanding level of security, some outsiders might think about joining it. The effective opportunity to join a successful grouping discourages non-member states from undermining the activities of the collective security organisation. At present, Ukraine, Georgia, and Moldova cannot 
be admitted to NATO because their accession could undermine NATO's unity. However, Ukraine and Moldova do not perceive NATO as a threat, since the alliance seems to be open to them. This is how 'networking power' shapes the incentives of those outside the grouping. The luring approach frequently includes the so-called conditionality principle ${ }^{49}$ which helps to maintain internal homogeneity and to restrain the enlargement process. If the effective opportunity to join turns into a formal opportunity, the strategy crumbles. This is what seems to have happened in Russia's relations with the West: even though Russia did participate in some Western fora, such as the Group of Eight (G8), it felt isolated and lamented that its position remained unheard..$^{\circ}$

\section{Appeasement}

When outsiders do not believe in their right to join the privileged grouping anymore or cannot be admitted to it for objective reasons (such as normative incompatibility), the collective security organisation can resort to the appeasement strategy. It implies retaining the faith of non-member states in the harmlessness of the grouping. If you never take advantage of your enormous opportunities, you are less likely to be seen as a threat. The strategy of convincing others that they have nothing to fear has certainly been employed by NATO. For instance, NATO has done quite a lot to show Moscow that European ballistic missile defence (BMD) is not directed against Russia..$^{\mathrm{I}}$ If the alliance had been successful in convincing Russia that Moscow has nothing to fear, most likely, the Kremlin would not have launched its hypersonic weapon programmes intended to overcome BMD.

\section{Self-confirmation}

If everyone believes in your good intentions and shares your values, the collective security organisation might lose its internal unity and cease to be a space of peace and cooperation. To prevent this from happening, the grouping needs to define a new set of adversaries and strategic objectives. Terrorists, WMD proliferators and rogue states are all depressingly familiar examples of enemies in an era of high international security standards. The return of great power competition with the rise of China and the resurgence of Russia have created quite typical external dangers for Western countries, leading to higher cohesion levels within NATO.

All this looks like a sophisticated combination of exclusion and inclusion mechanisms that can be used concurrently. The most reliable and loyal like-minded nations are admitted to the grouping, troublemakers are deterred, everyone else is encouraged to stay away. This is how NATO pursued an opendoor policy towards Central and Eastern Europe, fought terrorism in Afghanistan and nuclear proliferation in Korea, convincing Russians that they had nothing to 
fear. Such a strategic mix appears viable: minimal resources were used to combat fairly weak adversaries (primarily non-state actors), whereas interstate relations remained comparatively stable. The peacefulness of a collective security system increases when it becomes more inclusive and targets few and relatively weak enemies. The grouping anyway remains exclusive in its essence, as its unity is reinforced by the Other.

The balance looks particularly delicate. If you fail to prove your good intentions, outsiders can join forces to get rid of the exclusive grouping. If you let in every nation, the security guarantees will eventually be compromised.

As of 202I, the NATO collective security system remains fairly stable, although less inclusive than in the 20oos. Russia's interventions are far from enough to completely destabilise Western security institutions, but certainly enough to maintain their unity.

\section{Indivisible security and the world order}

As it is most likely impossible to maintain global hegemony or unipolarity indefinitely, major powers can simply acknowledge that they are different from one another and refrain from mutual threats. This is what the indivisible security principle calls for in general terms. However, the indivisible security model looks too weak to form the sole basis for a sustainable security architecture. The most obvious manifestation of equal security for every country is the Hobbesian war of all against all, under which nobody has access to security: the absence of some good actually eliminates the competition for it. If some good is present, the attempts to redistribute it appear inevitable.

Any military alliances embody unequal security, which is why they have no place in an inclusive world order. The key conceptual problem with that is the elusiveness of security arrangements based on presumed trust. If unconditional confidence in all international partners were a viable strategy, intelligence services, secret diplomacy and military alliances would never exist. Another challenge is that the same danger usually cannot be of the same importance for different nations. Latin American countries have no reason to care about the North Korean nuclear programme and even about Islamist terrorism, although these threats are usually defined as global. This is even more true when it comes to local and regional conflicts and challenges. Consequently, the insecurity of one nation can affect the well-being of all but is unlikely to do so on a global scale (although indivisible security theorists suggest otherwise ${ }^{52}$ ). Real interdependence in the security domain is currently present only in separate regions. There is room for argument about whether such interdependence exists in Asia or its subregions, and it is commonly said that it does exist in Europe. 
One of the most prominent functions of collective security organisations is to ensure joint action. Building on their common identity and perceived unity, NATO members can promptly react to different international crises without the need to coordinate their activity with outsiders. The indivisible security concept needs crisis response mechanisms that would be equally effective. The proponents of inclusive indivisible security posit that interactions in the international arena should be structured around particular problems and not around permanent coalitions. This is what some scholars and Russian officials call 'network diplomacy.53 They contend that we cannot force every nation to address global and regional challenges, since security interdependence has its limits, but what we can do is provide room for the involvement of all interested parties. The problem with this is that such 'flexible coalitions' would have little capacity to act. If Russia, Iran, the US and Turkey had formed a unified coalition to fight the Islamic State in Syria in 20I4, the outcome would probably have been miserable: a coalition cannot be successful having no common understanding of its goals and adversaries. Thus, when it comes to real action, inclusive flexible structures are likely to fragment into several unambiguous groupings. Repeated flexible coalitions of the same actors can evolve into permanent security organisations, taking us back to where it all began.

Furthermore, the international relations system needs actors that would create rules for it. The proponents of an inclusive world order usually favour the coordinating role of the United Nations, assuming that the decisions taken within the $\mathrm{UN}$ reflect the will of the international community. ${ }^{54}$ In practice, the elimination of exclusive decision-making instruments would hardly make a difference. Major powers promoting new international norms would lose exclusive international platforms, such as NATO, but they would simply advance their vision, building coalitions within inclusive institutions, e.g. by means of tabling resolutions at the United Nations General Assembly. Besides, international norms and principles are nothing without their implementation: the responsibility to protect doctrine was developed and unanimously endorsed within the $\mathrm{UN}^{55}$ and currently faces criticism from Russia and China for being misused to carry out humanitarian interventions. ${ }^{56}$ Therefore, the very use of inclusive institutions for decision-making does not safeguard us from conflicts arising from the implementation of decisions.

The non-binding nature of 'network diplomacy' is another challenge. If conflict resolution is the business of those interested, some conflicts will simply remain unsettled. The Yemeni Civil War (20I4 - present) has been a case in point: no major powers look really interested in settling the conflict, no binding security arrangements are present in the region and nobody is endeavouring to achieve reconciliation. Under a regional collective security system, such a situation would be virtually impossible. 
Punishing violators is a different issue at stake. If global politics is inclusive and nobody's security can be threatened, it is unclear how to prevent abuse under the indivisible security system. Collective security organisations pre-empt both external aggression and internal turbulence: outsider nations are deterred by the collective defence posture, whereas member states can face sanctions or alienation (and the resulting lower security level). Mechanisms of the UN favoured by the proponents of indivisible security are well suited for punishing small and weak countries, having no voice in the Security Council (as I said earlier, this is in fact an exclusive collective security mechanism), whereas the Security Council's permanent members are given carte blanche to do whatever they intend. Oddly enough, the indivisible security concept appears to privilege world powers, simultaneously depriving smaller nations of robust security guarantees.

Despite the above-mentioned flaws, some realistic steps could bring us closer to a genuinely inclusive world order based on indivisible security.

\section{Confidence-building measures}

If you bet on full and unconditional cooperation among nations with differing views, you need to eliminate or, at least, minimise mistrust in the international system. This would imply further empowerment of international watchdogs, some other form of 'mutual monitoring' or intergovernmental agreements with reliable verification mechanisms. These measures are unlikely to make competing nations work together within the 'network diplomacy' framework but certainly can discourage them from taking hostile action against one other. If countries are not fearful of each other, they will be less likely to make unreasonable decisions, threatening each other's security (e.g., missile defence development, military exercises, etc.). This basic premise sounds unbelievably simple, but its implementation has proved to be a highly complicated task. For example, Russia has repeatedly called into question the conclusions of the Organisation for the Prohibition of Chemical Weapons (OPCW) with respect to alleged violations of the Chemical Weapons Convention by Russia and its allies, ${ }^{57}$ even though the OPCW is designed as an impartial international watchdog.

\section{Arms control}

Arms control is the most evident practical manifestation of indivisible security. When nations do not develop weapons violating each other's interests, they do not strengthen their security at the expense of the security of others. Russia viewed America's withdrawal from the ABM Treaty and its decision to develop missile defence in Europe as a violation of the indivisible security principle precisely because these actions established an exclusive security level for NATO members and were seen to undermine global strategic stability. ${ }^{58}$ In the modern 
context, a renewed bilateral and multilateral dialogue should include hypersonic weapons and tactical nuclear weapons: the former are particularly destabilising, whereas the latter have never been truly controlled despite their long history.

Can the indivisible security concept come real? Apparently, it has already been partly implemented in several areas of collaboration, since some challenges are essentially global and affect the interests of states with divergent policy approaches. The threat of nuclear proliferation goes beyond political tensions, which is why joint efforts in the non-proliferation domain are possible, and 'flexible coalitions' do not disintegrate into exclusive groupings. A case in point would be North Korea: although Russia is sceptical of putting strong pressure on North Korea and calls for restraint, ${ }^{59}$ it did not veto the notably severe Security Council Resolution $2375^{60}$ in 2017 and managed to obtain a compromise with the United States. 'Network diplomacy' can also be useful when an immediate response is not needed and when different strategies are not mutually exclusive. There are a million ways to address food security issues, some of them have proved viable, and humanity will hardly ever choose a single correct path. Another example is official development assistance (ODA): there is no agreement on the most suitable forms of development aid, but competing approaches can complement each other. Finally, international watchdogs and transparency mechanisms are already there, although their effectiveness is often questionable.

\section{Reconciling the irreconcilable}

In real-world international politics, collective and indivisible security frameworks co-exist. Russia's hope for the establishment of a multipolar indivisible security system accommodating the interests of all actors in the foreseeable future is unrealistic, while the attempts to extend collective security principles throughout whole regions or even the entire world are doomed to failure.

What is the value of collective security for a future world order? First, it is the capacity to act together. Even if the strategy adopted by a grouping is controversial, a bad solution is often better than no solution. For example, if NATO had tried to find a middle ground with Russia in 1999 with respect to the Kosovo War, it would have failed to elaborate any substantive response to Milosevic's actions in Kosovo. Second, attractive and powerful groupings are pretty good at rulemaking: having agreed on some norm, they set an example for the whole international community, putting 'peer pressure' on other nations ${ }^{61}$ (humanitarian interventions are a case in point). Third, collective security organisations effectively deter external threats. World powers outside a grouping cannot escape responsibility for questionable activities using their veto in the UN Security Council, as they can still face sanctions by the powerful collective security organisation and its supporters. This was the case in 2014 after Russia's annexation of Crimea, although 
most non-military measures were formally adopted by the EU and some individual nations rather than by NATO. Further, collective security organisations discourage member states from imprudent actions: the United States usually tends to listen to NATO, having no incentive to alienate its closest allies, and the exceptions prove the rule. The Obama administration would probably not have intervened in Libya in 20II if the US had not managed to secure the support of European allies through the 'Leading From Behind' strategy. ${ }^{62}$

Although the indivisible security concept is hard to implement, it certainly has a role to play. I have shown that its 'network diplomacy' can be effectively applied in areas of cooperation with common strategic objectives, such as nuclear non-proliferation, or in fields that do not require immediate concerted action, such as food security and development aid. Further, some challenges cannot be single-handedly addressed by a separate grouping, as it might not have leverage over the actors involved in a particular situation (as was the case with North Korea). Finally, arms control and confidence-building measures, which belong to the indivisible security agenda, are relevant at any time, since growing military expenditure is never good news for political leaders.

How can the two competing concepts be reconciled in the years ahead?

\section{The leading collective security organisation is here to stay}

NATO is far from perfect. The Bosnia and Herzegovina intervention, the Kosovo War and the Libya intervention are only some examples of questionable operations by the alliance and its members. However, NATO's capacity to pursue real concerted multilateral policies is worth a lot. A flawed multilateral response by the alliance seems much better than unilateral actions by individual nations or a multilateral coordination failure in the 'network diplomacy' style.

\section{Self-restraint and equal treatment will help NATO to survive}

Watson's 'laws of history' heralding the end of unilateral advantages deal with classical empires that tended to exercise complete dominance over a particular territory. In general, dominance ends when its holder abuses it. If NATO continues its open-door policy towards like-minded nations and refrains from unnecessary provocative actions towards as many outsider countries as possible, the alliance can prolong its own existence. The point of no return has not been reached yet. Terrorism, WMD proliferation and civil wars are still there, great power competition is back, so NATO does have a basis for lasting internal unity.

\section{Arms control and confidence-building will reduce the risks}

It would be utopian to expect enduring political unity of the entire world. The leading collective security organisation will anyway face resistance from out- 
sider nations. New norms will be criticised, whereas NATO's approaches to conflict resolution are unlikely to satisfy every nation. Although it is possible to limit discontent, it is impossible to eliminate it. Therefore, risk reduction inevitably requires the development of arms control and confidence-building measures: even if political tensions cannot be avoided, they should not lead to unpredictable consequences. It is necessary to draw a clear line between day-to-day politics and strategic issues: the distinction between non-proliferation efforts and tactical disagreements is already there. Counter-terrorism also seems to enjoy special treatment. A similar logic might be extended to more areas of cooperation, and the indivisible security concept can be useful in this regard.

\section{Effectiveness should be a priority}

Inclusive cooperation in the international arena should not be at the expense of its effectiveness. Genuinely inclusive interaction can be possible if divergent efforts by different actors do not undermine each other or if actors with differing views pursue common strategic objectives. Food security, development aid and nuclear non-proliferation are only some of the areas of collaboration where these criteria could be observed. Besides, truly inclusive cooperation is indispensable if a problem cannot be tackled without the involvement of particular actors. This is the case with the North Korean nuclear programme: if we assume that military options are off the table, it is hardly possible to come to any real solution without China.

\section{Indivisible security and collective security in Russia's foreign policy}

It is generally believed that Russian foreign policy after I99I can be divided into periods that are different not only in substance but also in terms of Russia's vision of its global role, as well as ideas driving the policymaking process. The indivisible/collective security perspective calls this belief into question. Russia has certainly experienced domestic debates (especially over its relations with the West), but these debates have been present for decades. The specific mixture of competing approaches has resulted in a continuous foreign policy throughout the whole post-Soviet period, as far as its theoretical foundations are concerned. However, the relatively stable stance is riddled with internal inconsistencies due to the ongoing domestic disputes and because Russia itself is not really interested in the full-fledged implementation of its conceptual claims, which include the long-standing emphasis on indivisible security.

There is no denying the fact that in the I990s Russia was a better partner for Western countries than in the 20IOs and the early 2020s. However, the idea that Russia itself was very much different can be misleading. Russia has never adopted the 'security mindset' of NATO and EU countries. The way Russia was 
governed and the way Russia approached its foreign policy in the I990s was incompatible with Western values and approaches, just as it is now. In I993, Russian President Boris Yeltsin ordered the shooting of the White House in Moscow, which was the residence of Russia's Parliament. In legal terms, this was nothing but a coup. Nevertheless, Yeltsin was supported by the US and its allies. ${ }^{63}$ Further, Russia's military presence in the post-Soviet space is nothing new: in the early I990s, Moscow initiated a number of peacekeeping operations in the region, whose legal basis was not always solid. However, it is only later in the 2000 s that the debate on the issue gained traction. ${ }^{64}$ Finally, Russia's critical attitude to NATO was already evident in the mid-I99os amid the Operation Deliberate Force in Bosnia and Herzegovina ${ }^{65}$ and Washington's plans for NATO enlargement. ${ }^{66}$

What has changed since then is the way Russia reacts to political developments that it views as adverse, as well as Russia's perception of the world around it. As far as Moscow's reaction is concerned, today's Russia has many more foreign policy instruments than Russia had in the I990s. Russia possesses hypersonic weapons that can overcome ballistic missile defence ${ }^{67}$ Russia has a system of alliances in the post-Soviet space, even though these alliances seem to be not very effective. Russia has the ability to engage in local and regional conflicts, and it allegedly can influence domestic politics in other countries. ${ }^{68}$

Russia's perception of the world around it has evolved together with the practical implementation of the collective security and indivisible security principles. The early I990s were marked by productive cooperation with the West because Russia had two kinds of expectations. First, Russia believed it would become part of the collective security system established by privileged Western nations. This expectation manifested itself in Russia's desire to join Western institutions, such as the Group of Seven (G7) that turned into the Group of Eight (G8) after Russia's accession. Russia's relations with the West served as a new point of reference: Moscow virtually discontinued its cooperation with other former Soviet republics. Second, Russia believed that it would cease to be the target of hostile activities on the part of the West even if it failed to become a full-fledged Western nation. This is a manifestation of the indivisible security tradition.

Although Russia was included in some Western institutions, it did not become part of the Western collective security system, and this was already becoming evident in the mid-I99os. Moscow did not want to abandon its identity so as to be accepted to NATO, the EU and other Western organisations. Therefore, Russia had no option but to bet on indivisible security. In the beginning, this mechanism worked. President Yeltsin was supported by the West during grave 
political crises in $1993^{69}$ and $1996^{70}$ and faced little criticism with respect to his foreign policy. It means that the West refrained from reducing Russia's security despite Russia's non-compliance with Western standards.

This approach was gradually abandoned for understandable reasons. In the I990s, there was a realisation in the West that Communists' return to power in Russia would be a nightmare. Such a scenario was quite likely, which is why the strategy of supporting the Russian Government was the only viable option for Washington and its allies. Moreover, in the I990s, the US funded Russia's nuclear disarmament, ${ }^{7 \mathrm{I}}$ which was certainly in the interest of Washington. When Russia adopted a more assertive foreign policy stance in the 2000s, the West stopped tolerating Moscow's behaviour. In fact, Russia's partners refused to implement the indivisible security principle.

Moscow definitely abandoned its attempts to join Western exclusive security organisations. As Russia was unable to join them, it started preventing others from doing so. Russia did view NATO enlargement negatively in the I990s, but it did little to inhibit it. In the 2ooos, Moscow came up with its own regional integration projects, which were initially loose and could not be taken seriously. In the late 2000s and the early 20ios, the situation changed: the West and Russia imposed a zero-sum logic on such countries as Ukraine, Moldova and Belarus, making them choose a single integration path.

In fact, Moscow has attempted to establish its own exclusive institutions but has never acknowledged this fact. Russia views the Eurasian Economic Union and other arrangements in the post-Soviet space as a way to collectively participate in international cooperation from a position of strength. NATO enlargement and EU enlargement were based (and continue to be based) on individual negotiation tracks with individual nations. This means that the process of adjustment was one-sided and that Russia had no say in determining the future of its neighbouring countries. The West approached the problem from the perspective of sovereignty: as José Manuel Barroso, then President of the European Commission, put it in 2013, the era of 'limited sovereignty was over in Europe. ${ }^{72}$ Russia approached the problem from the perspective of indivisible security: Since a collective security framework not including Moscow was expanding, this framework was viewed as a threat to Russia.

Russia has come up with alternative conceptual approaches, although these approaches have not proved viable yet. Two notions need to be mentioned in this context: 'integration of integrations' and Greater Eurasia. ${ }^{73}$ Both concepts imply the establishment of a continuous Eurasian space consisting of integration projects and alliances that can work together on major issues. In the language of my paper, this means that several collective security frameworks can merge into a common space of indivisible security. 


\section{Indivisible security, Russia's foreign policy interests and collective benefit}

As can be seen, Moscow has been using the notion of indivisible security to justify its opposition to Western arrangements that allegedly reduce the security of Russia. What is not so obvious, however, is whether Russia would benefit from the full-fledged implementation of the concept. First, a world without NATO may turn out to be quite dangerous for Russia. If US troops and nuclear weapons were withdrawn from Europe, European countries would have no option but to build up their own military. Moreover, they would not necessarily be kinder to Russia than the US. As a result, Russia's security level would be further diminished.

Second, abandoning collective security organisations would be a burden for Russia in terms of conflict settlement efforts in neighbouring regions. If NATO fully withdrew from the Middle East, Russia would have to either accept a lower security level or devote its own resources to mitigating instability in the region.

Last but not least, Russia would have to engage in 'network diplomacy' (which Moscow has been advocating for recent decades). Moscow would have to refrain from unilateral military and political steps similar to those undertaken in Ukraine and Syria and cooperate with all nations who have a stake in resolving a particular issue, which appears quite difficult in the context of divergent interests.

If Russia wants to align the theoretical foundations of its policy with its behaviour, Moscow will have to acknowledge that the concept of indivisible security has only a limited applicability. The analysis in previous sections indicates that there is actually no real choice between indivisible and collective security outcomes. Russia cannot be included in NATO's 'area of peace and stability', as its opposition to the alliance's vision of the modern world order would undermine NATO's ability to pursue consistent substantive policies. Meanwhile, NATO cannot be simply dissolved, as it is the only multilateral international body capable of joint action and simultaneously the only example of an 'area of peace' based on mutual trust and common values. Waiting for a regime change in Russia is not a solution either: I have shown that the modern challenges are inherent in the very idea of collective security and do not seem to be specific to either Russia or NATO.

If policy makers aim to sustain and consolidate peace, it seems necessary to eliminate conditionality and linkages between different areas of cooperation. The logic of collective security and the logic of indivisible security should co-exist independently from each other, and neither of them can be allowed to 'hijack' world politics. When the collective security logic interferes in arms control or non-proliferation issues, strategic stability is undermined, and global risks increase, since narrow defence interests prevail over risk reduction. When indivis- 
ible security and 'network diplomacy' permeate tactical issues, terrorists and militias continue to commit violations with impunity, and international rules are not enforced, as concerted action and binding arrangements give way to endless fruitless negotiations.

The decoupling of different policy areas would definitely reduce the international risks and appears to be a viable way out of the current European security crisis. If imbalances in one sphere did not spread to other areas of collaboration, the general stability of international affairs would be notably enhanced. This approach is already being widely implemented: not only non-proliferation efforts but also people-to-people contacts, as well as economic cooperation, represent the areas of Russia's relations with the West that have remained largely unaffected by political disagreements.

Some international relations experts have already called for what I am referring to as the decoupling of policy areas. Remler has come up with the idea of compartmentalisation, which again implies dividing policy concerns into areas of concern. As he put it, '[a] sustainable, effective dialogue can only be restarted if both sides tone down the rhetoric, agree not to lecture one another, and compartmentalize major demands (on the understanding that they are not dropping those demands). The process should start with an agreement to talk about specific, circumscribed topics that cannot be highly politicized, setting modest goals. ${ }^{37}$

However, the decoupling/compartmentalisation logic comes up against holism, that is, the tendency to see politics as an integral whole. The well-known domino theory implies that 'a defeat or retreat on one issue $\langle\ldots\rangle$ is likely to produce $\langle\ldots\rangle$ further demands on the state, 75 whereas the 'holistic logic' assumes that even cooperation in a particular domain can give undue advantage to the adversary in other areas. New START is America's unilateral disarmament, ${ }^{76}$ the delivery of Russian gas to Europe enables the Kremlin to pursue a more hawkish foreign policy ${ }^{77}$ - such ideas are all manifestations of this approach. The result is the politicisation of almost all areas of Russia's relations with the West, which makes the development of productive cooperation a highly difficult task. The more outsider nations are marginalised and antagonised by the leading collective security grouping, the more quickly will this grouping cease to exist as a result of growing external pressure.

Both Russia and the West should finally recognise that their concepts of security have limits. Such a recognition would certainly increase the likelihood of achieving a mutually beneficial settlement.

\section{Conclusion}

In this paper, I have tried to add to the conceptualisation of collective security and indivisible security, taking into account the developments of recent 
decades in Russia's relations with the West. I define collective security as an exclusive arrangement based on providing security for a limited number of nations meeting some specific criteria. Collective security organisations are good at ensuring joint action, creating regional and global rules, and punishing those who violate the rules. However, exclusive organisations face the challenges of maintaining political unity and countering those outsiders who do not have the incredible level of security enjoyed by the insiders and want to disrupt such an organisation.

To maintain their unity and prolong their existence, collective security institutions can use the strategy of luring, the appeasement strategy, and the strategy of self-confirmation. The use of these three approaches helps exclusive organisations both maintain their unity and prevent the emergence of severe external threats.

I define indivisible security as an inclusive arrangement building on the provision of equal security for all nations without any specific preconditions. An indivisible security framework can serve as a basis for confidence-building measures and arms control, but it is a bad framework when it comes to problem areas where actors have divergent interests. Therefore, it is very poor at ensuring joint action, rule-making, and addressing conflicts that are of little interest to major powers. I demonstrate that many of Russia's foreign policy steps of recent decades have been consistent with the indivisible security logic, contrary to the belief that the conceptual basis of Russia's strategy has changed significantly since the ig9os.

I show that neither collective security nor indivisible security can serve as the sole basis for the modern world order and come up with the idea of decoupling different policy areas from each other and applying the two concepts to areas where they can be really useful. Further, I state my disagreement with the holistic approach to international politics, since it makes any dialogue on selected issues virtually impossible.

The complete and irrevocable cessation of cooperation in retaliation for any non-existential threat is a poor strategy, as it does not pay off and can undermine the world order based on cooperation. If more and more countries face exclusion and marginalisation, the status-quo coalition will eventually disappear. An indivisible security order would not be any better, since it is apparently too weak to maintain the rules-based international system. However, there is another way: the leading collective security organisation can further carry out its indispensable functions, settling conflicts and ensuring concerted action. In doing so, it does not need to antagonise important actors of global politics, excluding them from decision-making processes in areas of international cooperation where the logic of indivisible security appears applicable. If retaliatory measures in response to wrongdoing remain limited in scope and if outsider nations feel 
secure, the international winning coalition will be large enough to maintain stable interstate relations.

\section{Endnotes}

I See Robert Jervis (I978), 'Cooperation Under the Security Dilemma,' World Politics 30(2), pp. I67-2I4; Avidit Acharya and Kristopher W. Ramsay (2013), 'The Calculus of the Security Dilemma,' Quarterly Journal of Political Science 8(2), pp. I83-203.

2 See Ben Buchanan (2016), The Cybersecurity Dilemma: Hacking, Trust and Fear Between Nations, New York: Oxford University Press.

3 See Samuel Charap and Mikhail Troitskiy (2013), 'Russia, the West and the Integration Dilemma,' Survival 55(6), pp. 49-62, available at: <https://doi.org/Io.Io8o/00396338.20 I3.862935> (accessed 30 May 202I).

4 See, for example, Iver B. Neumann (1999), Uses of the Other: "The East" in European Identity Formation, Minneapolis: University of Minnesota Press.

5 See Immanuel Kant (2003), To Perpetual Peace: A Philosophical Sketch, Indianapolis: Hackett Publishing Company.

6 League of Nations (I919), 'Covenant of the League of Nations,' available at: <https:// www.refworld.org/docid/3dd8b9854.html> (accessed 22 May 202I)

7 NATO (202I), 'Collective defence - Article 5, available at <https://www.nato.int/cps/ en/natohq/topics_II0496.htm $>$ (accessed 22 May 202I).

8 I admit that the distinction between 'collective defence' and 'collective security' is a bit blurred in this article, but this actually reflects the current situation in global politics. A collective security system must be based on real security guarantees and mutual obligations, and it would be an exaggeration to say that the UN and other inclusive multilateral institutions provide for anything of that nature. Some researchers believe that the I998-99 Kosovo War is the moment when NATO was transformed into a collective security organisation. See, for instance, Stefan Popov (I999), 'NATO Expansion: From Collective Defence to Collective Security,' Perspectives (I3), pp. 59-67.

9 'From the Treaty to the Organization,' Collective Security Treaty Organization, available at: < https://en.odkb-csto.org/25years/> (accessed 22 May 202I).

Io Marc Perrin de Brichambaut (20I0), 'The Indivisibility of Euro-Atlantic Security,' Speech at the I8th Partnership for Peace Research Seminar, Vienna Diplomatic Academy, 4 February, p. I, available at: <https://www.osce.org/sg/4I452> (accessed 30 May 202I).

II Ibid., p. 3 .

I2 It has been argued that 'security is indivisible' pledges can contribute to misperceptions. See D. Yost (1998), 'The new NATO and collective security', Survival 40(2), p. I46, available at: <https://www.tandfonline.com/doi/abs/Io.Io80/00396338.I998.IoIo784 6> (accessed 30 May 202I).

I3 See Charter of Paris for a New Europe (I990), adopted 2I November, Organization for Security and Co-operation in Europe, p. 5, available at: <https://www.osce.org/ mc/395I6> (accessed 30 May 202I).

I4 See Founding Act on Mutual Relations, Cooperation and Security between NATO and the Russian Federation (I997), adopted 27 May, Paris, available at: <https://www. nato.int/cps/en/natohq/official_texts_25468.htm> (accessed 30 May 202I).

I5 See Charter for European Security (I999), adopted I8 November, Organization for Security and Co-operation in Europe, p. I, available at: <https://www.osce.org/ $\mathrm{mc} / \mathrm{I} 7502>$ (accessed 30 May 202I).

I6 See, for example, Foreign Policy Concept of the Russian Federation (2016), adopted 
30 November, available at: <https://www.mid.ru/en/foreign_policy/official_ documents/-/asset_publisher/CptlCkB6BZ29/content/id/2542248> (accessed 30 May 202I).

I7 Geoffrey Lee Williams, Barkley Jared Jones (200I), 'Collective Security or Collective Defence?' In: NATO and the Transatlantic Alliance in the 2Ist Century. Palgrave Macmillan, London, p. 88, available at: <https://doi.org/Io.I057/9780230599079_8> (accessed 22 May, 202I).

I8 Ibid., p. 88.

I9 Ibid., p. 89.

20 Ibid., p. 90.

2I Ibid., p. 92.

22 Charles A. Kupchan, Clifford A. Kupchan (I995), 'The Promise of Collective Security,' International Security, 2O(I), p. 53, available at: <https://doi.org/I0.2307/25392I5> (accessed 22 May, 202I).

23 lbid., p. 53.

24 lbid., p. 54.

25 John J. Mearsheimer (I994), 'The False Promise of International Institutions,' International Security, I9(3), p. 28, available at <https://doi.org/I0.2307/2539078> (accessed 22 May, 202I).

26 Ibid., p. 29.

27 Ibid., pp. 29-30.

28 Michael MccGwire (I998), 'The Indivisible Continent: Russia, NATO and European Security.' In: McSweeney B. (eds) Moral Issues in International Affairs. Palgrave Macmillan, London, p. I40, available at <https://doi.org/Io.I0o7/978-I-349-264643-7> (accessed 22 May, 202I).

29 Ibid., p. I5I.

30 Ibid., p. I7I.

3I Andrei Zagorski (2014), 'Strengthening the OSCE. Building a Common Space for Economic and Humanitarian Cooperation, an Indivisible Security Community from the Atlantic to the Pacific,' RIAC, Moscow: Spetskniga, p. I5.

32 Rachel Ellehuus \& Andrei Zagorski (2019), 'Restoring the European Security Order,' Center for Strategic and International Studies, p. 3, available at <https:// russiancouncil.ru/papers/CSIS-RIAC-Ellehuus-Zagorski-RestoringEuropeanOrder. pdf $>$ (accessed 22 May 202I).

33 Philip Remler (2019), 'Russia and Cooperative Security in Europe: Times Change, Tactics Remain,' Carnegie Endowment for International Peace, available at: <https:// carnegieendowment.org/20I9/o8/or/russia-and-cooperative-security-in-europetimes-change-tactics-remain-pub-796II> (accessed 22 May 202I).

34 See Manuel Castells (20II), 'A Network Theory of Power,' International Journal of Communication, Vol. 5: pp. 773-787, available at: <https://ijoc.org/index.php/ijoc/ article/view/ı136> (accessed 30 May 202I).

35 Excerpts from Foreign Minister Sergey Lavrov's Answers at the Meeting with Students and Faculty of the Azerbaijan Diplomatic Academy (2017), 20 November, Baku, available at: <https://missiontonato.mid.ru/web/nato-en/-/excerpts-from-foreignminister-sergey-lavrov-s-answers-at-the-meeting-with-students-and-faculty-ofthe-azerbaijan-diplomatic-academy-baku-november-20-?inheritRedirect=true> (accessed 30 May 202I).

36 Ibid.

37 See Treaty on Conventional Armed Forces in Europe (I990), adopted i9 November, Organization for Security and Co-operation in Europe, available at: <https://www. osce.org/library/I4087> (accessed 30 May 202I).

38 See Treaty between the United States of America and the Union of Soviet Socialist Republics on the Limitation of Anti-Ballistic Missile Systems (I972), adopted 26 May, 
Moscow (no longer in force), available at: <https://reaties.un.org/pages/showDetails. aspx?objid=0800000280ioceda $>$ (accessed 30 May 202I).

39 See Stéfanie von Hlatky, Michel Fortmann (2020), 'NATO enlargement and the failure of the cooperative security mindset,' International Politics 57, pp. 554-572, available at: <https://doi.org/I0.I057/s4I3II-020-00240-W> (accessed 22 May 202I).

40 See Adam Watson (1992), The Evolution of International Society, London: Routledge, pp. I6-I7.

4I See, for example, Paul Kennedy (I988), The Rise and Fall of the Great Powers: Economic Change and Military Conflict from 1500 to 2000 , London: Unwin Hyman.

42 See Joseph S. Nye (I990), Bound to lead: The Changing Nature of American Power, New York: Basic Books; Joseph S. Nye (2019), 'The rise and fall of American hegemony from Wilson to Trump', International Affairs 95(I), pp. 63-80.

43 See Monika Sieradzka (2019), 'Poland: More aligned to US than to European partners?' DW, available at: <https://www.dw.com/en/poland-more-aligned-to-us-than-toeuropean-partners/a-50232484> (accessed 23 May 202I).

44 Petersberg Declaration made by the WEU Council of Ministers (I992), available at: <https://www.cvce.eu/en/obj/petersberg_declaration_made_by_the_weu_council_ of_ministers_bonn_I9_june_I992-en-I6938094-bb79-4Iff-95Ic-f6c7aae8a97a.html> (accessed 23 May 202I).

45 Voice of America (20I8), 'Vice-prem'er RF zajavil, chto kompleks «Avangard» sposoben obojti ljubuju sistemu PRO' [Russian Deputy Prime Minister Says the Avangard System Can Overcome Any Missile Defence System], available at: <https://www. golosameriki.com/a/associated-press-new-official-russian-weapon/47I8I88.html> (accessed 23 May 202I).

46 Kingston Reif (2015), 'Russia Completes CFE Treaty Suspension,' Arms Control Today, available at: <https://www.armscontrol.org/act/2015-04/news-briefs/russiacompletes-cfe-treaty-suspension $>$ (accessed 23 May 202I).

47 Abigail Abrams (20I9), 'Here's What We Know So Far About Russia's 20I6 Meddling,' Time, available at: <https://time.com/5565991/russia-influence-2or6-election/> (accessed 23 May 202I).

48 Andrew S. Weiss (2020), 'With Friends Like These: The Kremlin's Far-Right and Populist Connections in Italy and Austria,' Carnegie Endowment for International Peace, available at: <https://carnegieendowment.org/2020/02/27/with-friendslike-these-kremlin-s-far-right-and-populist-connections-in-italy-and-austriapub-8IIoo > (accessed 23 May 202I).

49 The conditionality principle implies that outsider nations can be admitted to an organisation only if they reform their policies. This principle has been widely used by the European Union.

50 In early 202I, I had the honour to participate in a discussion with a Russian diplomat who has personal experience in Russia's interaction with multilateral fora. As he put it, Russia felt isolated in the G8 well before 20I4. Typically, there were two positions present during G8 summits: the joint position of the seven Western countries and the position of Russia.

5I See, for instance, Bilyana Lilly (2015), 'How Putin uses missile defence in Europe to distract Russian voters', NATO Review, available at: <https://www.nato.int/docu/ review/articles/2015/oI/29/how-putin-uses-missile-defence-in-europe-to-distractrussian-voters/index.html $>$ (accessed 23 May 202I).

52 For example, in 2007 Vladimir Putin cited Franklin D. Roosevelt to substantiate Russia's case for indivisible security: "When peace has been broken anywhere, the peace of all countries everywhere is in danger." See President of Russia (2007), 'Speech and the Following Discussion at the Munich Conference on Security Policy, available at: <http:// www.en.kremlin.ru/events/president/transcripts/24034> (accessed 23 May 202I).

53 See Charles E. Ziegler (20I8), 'Diplomacy', in Andrei P. Tsygankov, Routledge 
Handbook of Russian Foreign Policy, Abingdon: Routledge, pp. I3I-I32; Sergey Lavrov (2007), 'The Present and the Future of Global Politics,' Russia in Global Affairs, Issue 2, available at: <https://eng.globalaffairs.ru/number/n_8554> (accessed 30 May 202I).

54 Philip Remler (2020), 'Russia at the United Nations: Law, Sovereignty, and Legitimacy,' Carnegie Endowment for International Peace, available at: <https:// carnegieendowment.org/2020/oI/22/russia-at-united-nations-law-sovereignty-andlegitimacy-pub-80753> (accessed 23 May 202I).

55 See 'The Responsibility to Protect: Report of the International Commission on Intervention and State Sovereignty' (200I), Ottawa: International Development Research Centre; 2005 World Summit Outcome (2005), A/RES/6o/I, adopted I6 September, p. 30, available at: <https://www.un.org/en/development/desa/ population/migration/generalassembly/docs/globalcompact/A_RES_6o_I.pdf> (accessed 30 May 202I).

56 See Vladimir Baranovsky and Anatoly Mateiko (2016), 'Responsibility to Protect: Russia's Approaches,' The International Spectator 5I(2), pp. 49-69.

57 Hanna Notte (2020), 'Russia and Ongoing Challenges to the Chemical Weapons Convention,' James Martin Center for Nonproliferation Studies, available at: <https:// nonproliferation.org/russia-and-ongoing-challenges-to-the-chemical-weaponsconvention/> (accessed 23 May 202I).

58 'Putin: U.S. ABM move "a mistake" (200I), CNN, I3 December, available at: <https:// edition.cnn.com/200I/WORLD/europe/12/13/russia.abm/index.html> (accessed 30 May 202I).

59 'Nebenzya: Rossija ne priemlet pretenzii KNDR na obretenie statusa jadernojj derzhavy' [Nebenzya: Russia Rejects North Korea's Quest to Obtain a Nuclear Power Status] (2017), TASS, 30 November, available at: <https://tass.ru/politika/4770979> (accessed 30 May 202I).

6o Security Council Resolution 2375, Non-proliferation/Democratic People's Republic of Korea (20I7), S/RES/2375, adopted II September, available at: <http://unscr.com/en/ resolutions/doc/2375> (accessed 30 May 202I).

6I The term 'peer pressure' was used in 1998 by M. Finnemore and K. Sikkink to refer to 'the cumulative effect of many countries in a region adopting new norms.' See Martha Finnemore and Kathryn Sikkink (1998), 'International Norm Dynamics and Political Change,' International Organization 52 (4), pp. 887-9I7.

62 See, for example, Roger Cohen (20II), 'Leading From Behind,' The New York Times, available at: <https://www.nytimes.com/20II/II/or/opinion/oriht-edcohenor.html> (accessed 23 May 202I).

63 See Roman Goncharenko (2018), 'Russia's I993 crisis still shaping Kremlin politics, 25 years on,' DW, available at: <https://www.dw.com/en/russias-I993-crisis-stillshaping-kremlin-politics-25-years-on/a-45733546> (accessed 27 May 202I).

64 Wade Boese (2004), 'Dispute Over Russian Withdrawals From Georgia, Moldova Stall CFE Treaty,' Arms Control Association, available at: <https://www.armscontrol.org/ act/2004-09/dispute-over-russian-withdrawals-georgia-moldova-stall-cfe-treaty> (accessed 29 May 202I).

65 Carol J. Williams (1995), 'Yeltsin Lashes Out at NATO Strikes in Bosnia,' Los Angeles Times, available at: <https://www.latimes.com/archives/la-xpm-I995-09-09-mn44006-story.html> (accessed 29 May 202I).

66 Roger Cohen (1993), 'Yeltsin Opposes Expansion Of NATO in Eastern Europe,' The New York Times, available at: <https:/www.nytimes.com/1993/Io/o2/world/yeltsinopposes-expansion-of-nato-in-eastern-europe.html>.

67 Voice of America (20I8), 'Vice-prem'er RF zajavil, chto kompleks «Avangard» sposoben obojti ljubuju sistemu PRO' [Russian Deputy Prime Minister Says the Avangard System Can Overcome Any Missile Defence System], available at: <https://www.golosameriki.com/a/ associated-press-new-official-russian-weapon/47I8188.html > (accessed 23 May 202I). 
68 Abigail Abrams (2019), 'Here's What We Know So Far About Russia's 20i6 Meddling,' Time, available at: <https://time.com/5565991/russia-influence-2or6-election/> (accessed 23 May 202I).

69 Roman Goncharenko (20I8), 'Russia's I993 crisis still shaping Kremlin politics, 25 years on,' DW, available at: <https://www.dw.com/en/russias-I993-crisis-still-shapingkremlin-politics-25-years-on/a-45733546> (accessed 27 May 202I).

70 Alessandra Stanley (I996), 'Moscow Journal; The Americans Who Saved Yeltsin (Or Did They?), available at: <https://www.nytimes.com/1996/07/o9/world/moscowjournal-the-americans-who-saved-yeltsin-or-did-they.html $>$ (accessed 30 May 202I).

7I Justin Bresolin (20I4), 'Fact Sheet: The Nunn-Lugar Cooperative Threat Reduction Program,' Center for Arms Control and Non-Proliferation, available at: <https:// armscontrolcenter.org/fact-sheet-the-nunn-lugar-cooperative-threat-reductionprogram/> (accessed 30 May 202I).

72 BBC News (20I8), 'EU rejects Russia “veto” on Ukraine agreement,' available at: <https://www.bbc.com/news/world-europe-251546I8> (accessed 29 May 202I).

73 See Andrej Krickovic \& Igor Pellicciari (202I), "From "Greater Europe" to "Greater Eurasia": Status concerns and the evolution of Russia's approach to alignment and regional integration,' Journal of Eurasian Studies, I2(I), pp. 86-99, available at: <https://doi.org/Io.II77/I87936652I998808> (accessed 30 May 202I); Timofei Bordachev (2019), 'Greater Eurasia: What Is Yet To Be Done?' available at: < https:// valdaiclub.com/a/highlights/greater-eurasia-what-is-yet-to-be-done/> (accessed 30 May 202I).

74 Philip Remler (2019), 'Russia and Cooperative Security in Europe: Times Change, Tactics Remain, Carnegie Endowment for International Peace, available at: <https:// carnegieendowment.org/20I9/o8/or/russia-and-cooperative-security-in-europetimes-change-tactics-remain-pub-796II> (accessed 22 May 202I).

75 Robert Jervis (20I7), How Statesmen Think: The Psychology of International Politics, Princeton; Oxford: Princeton University Press, p. 236.

76 John Bolton (20I0), 'New Start Is Unilateral Disarmament,' WSJ, available at: <https:// www.wsj.com/articles/SBioooi424052748703618504575459511831427690> (accessed 30 May 202I).

77 Reuters (2019), 'Ukraine decries Nord Stream 2 approval, says it weakens Europe,' available at: <https://www.reuters.com/article/us-ukraine-nato-idUSKBNiXAi85> (accessed 30 May 202I). 